to terra firma." It is rather surprising to find at so early a date a project for an elevated railroad on Broadway and, a few pages farther on, plans for what is usually regarded as the recent innovation of making ice by machinery. Comment and criticism extend even so far as to include chemical research, romance, poetry, religion and phrenology.

Studies of the past from contemporaneous sources are always interesting, and when they deal with ideas on which today are founded the conveniences and essentials of modern living, they become doubly so.

\title{
An Industrial Endorsement
}

THE Associated Industries of Massachusetts has recently given the Business Historical Society its endorsement, and in its weekly periodical - "Industry" - there has already appeared a two-page article descriptive of the purposes and functions of this Society.

To other industrial associations of like nature, we would say "Go thou and do likewise!" As "Industry" remarks, "In your offices, storehouses, attics are undoubtedly many old reports, pamphlets, books and so forth, which are of little value to you but which would make valuable addition to the collection of the Business Historical Society's library. Look them up. . . Push the good work along. It is very much needed."

\section{The Price of Slaves}

THERE has recently come to the Library a small collection of official "Appraisements of Estates," all from Jefferson County, Georgia, and in date running from 1800 to 1820 . These appraisements give an excellent idea of the nature of the small slave-holding estate of that period, the commodities, tools and implements upon it, the stock of household goods and the price of slaves. Most of the estates appraised have only a few slaves, not more than thirteen. Of course it was a period of large price fluctuations, but on an average a man slave appears to have been valued at about five hundred dollars, a woman at three hundred, and a boy or girl at two hundred. The value of an estate, apart from the slaves, was, as a rule, small. Thus one with ten slaves, who were put in at \$2955, 
totalled $\$ 4$ I 20 . Another, with seven slaves worth \$1900, came to $\$ 2897$. Estates with one or two slaves were of trivial amounts apart from the slaves.

Those who are interested in the subject will find here excellent material for comparison with the findings of some such standard book on the subject as Phillips's American Negro Slavery.

\section{The Williams Fuel Collection}

THE above title is used to designate temporarily the numerous runs of chemical engineering journals for the period I $890-1920$ which have just come in by purchase from the library of $\mathrm{H}$. J. Williams. Mr. Williams was for many years the chemical expert in the fuel division of the Boston Elevated Railway Company. This mass of material will be especially interesting to students concerned in those aspects of industry in which fuel consumption plays a prominent part, as its original purpose was to give information which would be useful in the purchase of the most satisfactory and economical type of fuel for the operation of the Elevated - coal, oil, or whatever it might be.

There are many reports from the Geological Surveys, both state and federal, also sets of such publications as the Proceedings of the American Chemical Society and the Journal of the Society of Chemical Industry (London). It is a convenient concentration of material just a bit out of the ordinary path of business history.

\section{New England's Cotton Mills}

How the Records for their Story Were Discovered To write the history of an industry in the days before income-tax returns and statistical departments is a baffling task. In the absence of complete records of any sort, - for the industry, for a locality, or even for a single company, - every scrap of evidence becomes a pearl of great price. Every production sheet or worker's contract, every order for machinery or letter about the business, must be used to fill in the blank spaces of the picture. The writer, in trying to piece together in this way the history of the first sixty years of the New England cotton industry, I790-1 $85^{\circ}$, was led into an absorbing treasure hunt which took her throughout the length 